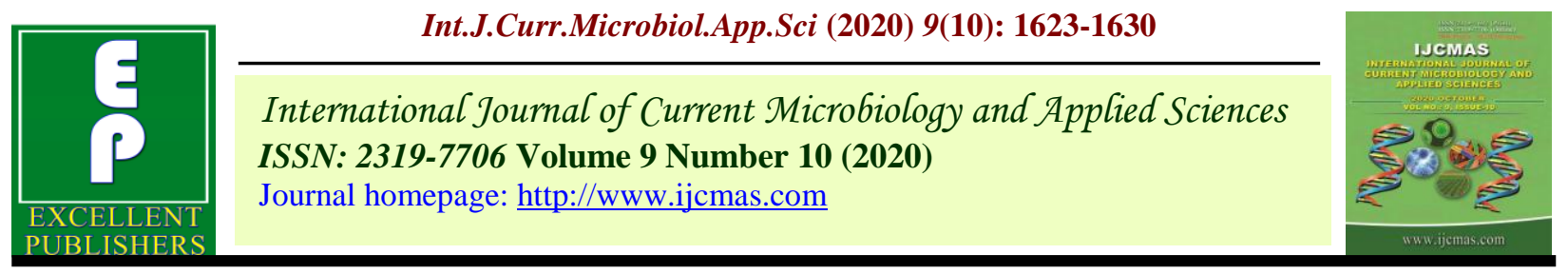

Original Research Article

https://doi.org/10.20546/ijcmas.2020.910.194

\title{
Experimental Analysis of Solar Photovoltaic System under Partial Shading
}

\author{
Parul Mertia*, Surendra Kothari, Navneet Agrawal and N. L. Panwar \\ Department of Renewable Energy Engineering, College of Technology and \\ Engineering, Maharana Pratap University of Agriculture and Technology, \\ Udaipur, Rajasthan 313001 India \\ *Corresponding author
}

\section{A B S T R A C T}

\begin{tabular}{|l|}
\hline Ke y w o r d s \\
$\begin{array}{l}\text { Solar photovoltaic, } \\
\text { Partial shading, } \\
\text { Bypass diode }\end{array}$ \\
\hline Article Info \\
$\begin{array}{l}\text { Accepted: } \\
\text { 12 September } 2020 \\
\text { Available Online: } \\
\text { 10 October } 2020\end{array}$ \\
\hline
\end{tabular}

\section{Introduction}

The ever-increasing demand for low-cost energy and growing concern about environmental issues has generated enormous interest in the utilization of nonconventional energy sources such as the solar energy. The freely and abundantly available solar energy can be easily converted into electrical energy using photovoltaic (PV) cells. A PV source has the advantage of low maintenance cost, absence of moving parts, and pollution-free energy conversion process (1). However, a major drawback of the PV source is its ineffectiveness during the nights or low insolation periods or during partially shaded conditions (2). Partial shading can occur when the PV arrays get covered by shadows of passing clouds, buildings, trees, poles or utilities, etc the shaded cells can produce lesser amount of current than unshaded modules(3). As all the cells are seriesconnected to form a module, the same amount of current should flow through every cell. And thus, the unshaded cells will impose the shaded cells to allow more current than their short circuit current. Thus, operating at a negative voltage is the only possible way such that the shaded cells operate at a current greater than the short circuit current. This leads to a net voltage loss in the system. Shaded cells act as load and they absorb 
power. Consequently, current in the series string cannot be greater than the current of the solar cell with lowest illumination (4). Moreover, the power losses in the individual shaded cells would result in local heating. The temperature of the cell would increase and affect the neighbouring cells. This cause thermal stress and causes local hot spots, resulting in total failure of the entire array (5).

The partial shading condition also results in multiple peaks on the P-V characteristics and the conventional MPPT techniques, designed suitably for single peak, do not work well under such conditions (6).

These multiple maxima points occur due to the connection of bypass diodes which are used to prevent hotspots formation when some modules in a string receive less irradiation than other modules (7). Thus, design of a MPPT technique that would track the global maximum power in shaded arrays is highly imperative.

\section{Materials and Methods}

\section{Experimental Description}

The experimental study for examination of energy extraction characteristics is presented for different configurations of $40 \mathrm{~W}$ PV module. The "Solar PV Training and Research Kit" was used to obtain characteristics of PV module. This kit mainly consists of a control unit and two polycrystalline modules having 36 series connected solar cells. The Control Unit has a pot meter and it displays the voltage and current.

Pot meter works as a variable load for the module. When load on the module is varied by pot meter $(0-200 \mathrm{ohm})$ the current and voltage of the module gets changed which shift the operating point on $\mathrm{I}-\mathrm{V}$ and $\mathrm{P}-\mathrm{V}$ characteristics. The solar radiations were measured by solar power meter. Readings for voltage and current were taken at an incident radiation of approximately $1000 \pm 80 \mathrm{~W} / \mathrm{m}^{2}$ for different configuration of PV modules. I$\mathrm{V}$ and $\mathrm{P}-\mathrm{V}$ characteristics were achieved by following connections in control board (8). The configurations taken were single module, series connected modules with and without bypass diode and parallel connected modules.

These configurations were also used for the study of PV system under the effect of partial shading. The shading effect was carried out in two different ways. Hard shading was done by placing cardboard sheets on 1-cell, 3-cells, 6-cells, 9-cells and whole module and $25 \%$ (i.e., 9-cells) soft shading was done on single module by keeping the cardboard sheet above the module.

Each shading condition was analyzed and compared with un-shaded condition by plotting the I-V and P-V characteristics. The series connection was analyzed with and without bypass diode under both shaded and un-shaded condition.

\section{Results and Discussion}

\section{Energy extraction characteristics for different configurations of $40 \mathrm{~W}$ PV module}

The energy extraction characteristics i.e., I-V and $\mathrm{P}-\mathrm{V}$ curves were obtained for different configuration of PV module (Fig. 1). Fig. 2 shows I-V curve and Fig. 3 shows P-V curve for different module connections. PV modules show non linear characteristics therefore, the curve shows that at lower voltages, the current is less dependent on voltage but at higher voltage, the current drops steeply with increasing voltage. For single module under un-shaded condition highest current achieved was $2.21 \mathrm{~A}$ and highest voltage was $20 \mathrm{~V}$ with maximum power of $32.96 \mathrm{~W}$. 
Fig.1 Experimental setup for energy extraction characteristics

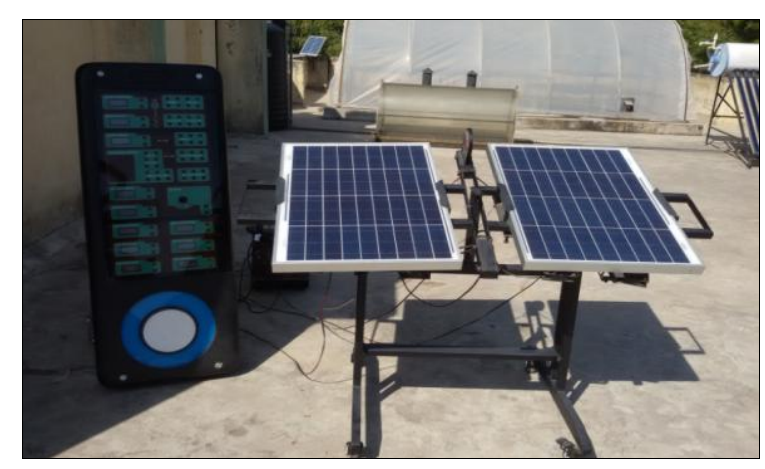

Fig.2 I-V curve for different configuration of PV modules

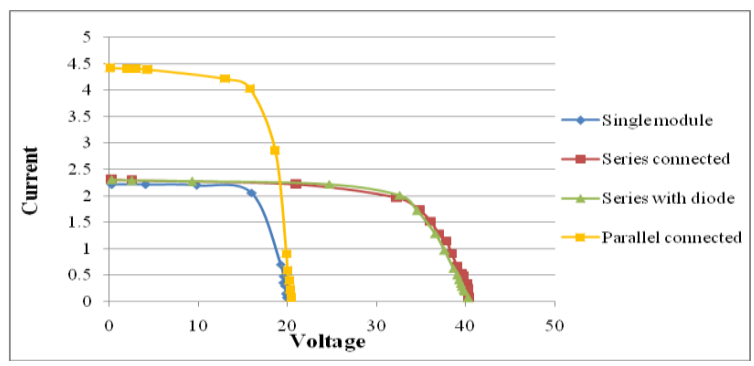

Fig.3 P-V curve for different configuration of PV modules

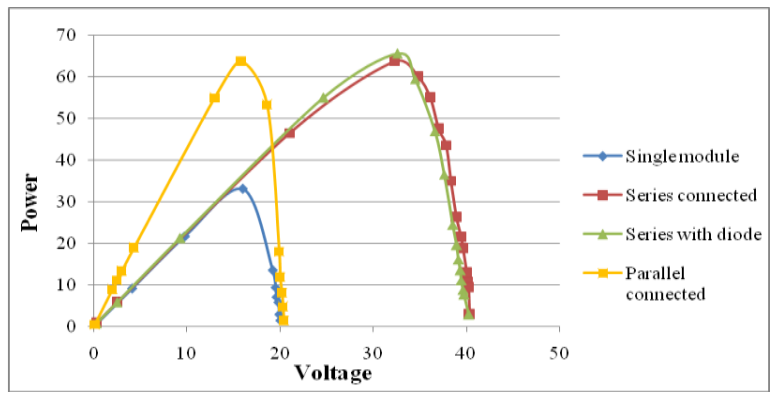

Fig.4 I-V curve for single PV module under different shading conditions

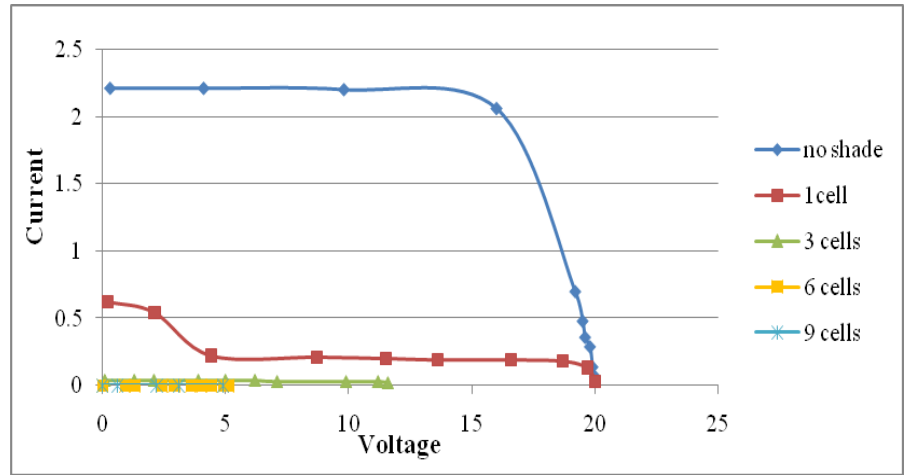


Fig.5 P-V curve for single PV module under different shading conditions

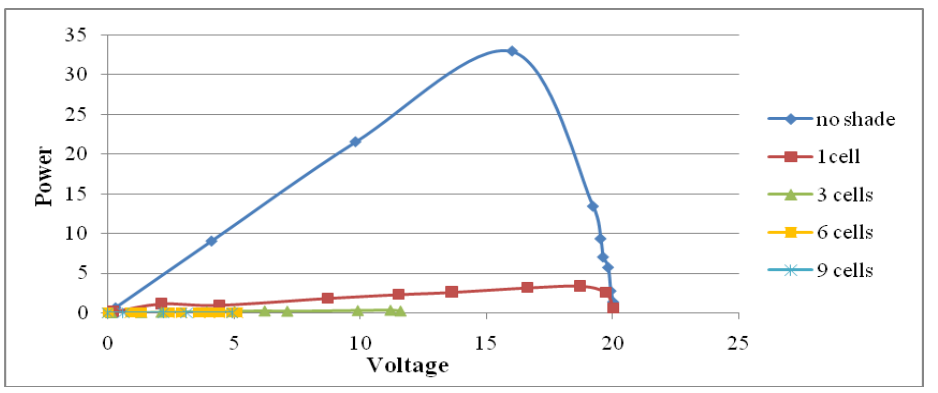

Fig.6 I-V curve for series connected PV modules without bypass diode under different shading conditions

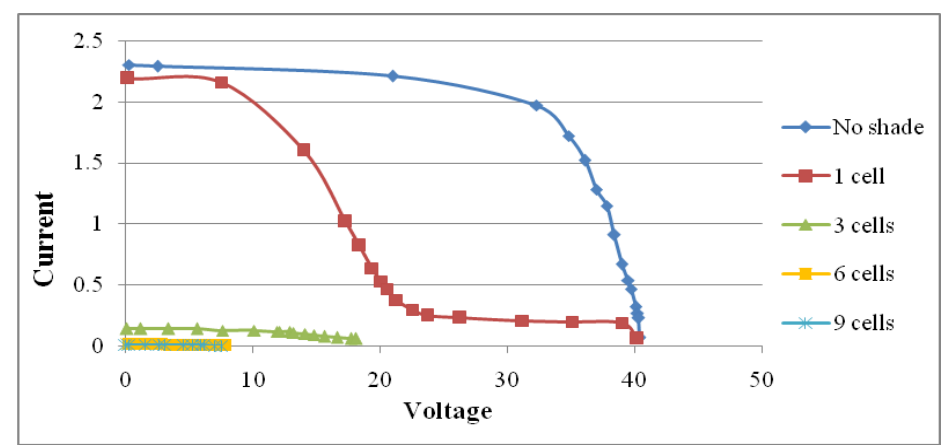

Fig.7 P-V curve for series connected PV modules without bypass diode under different shading conditions

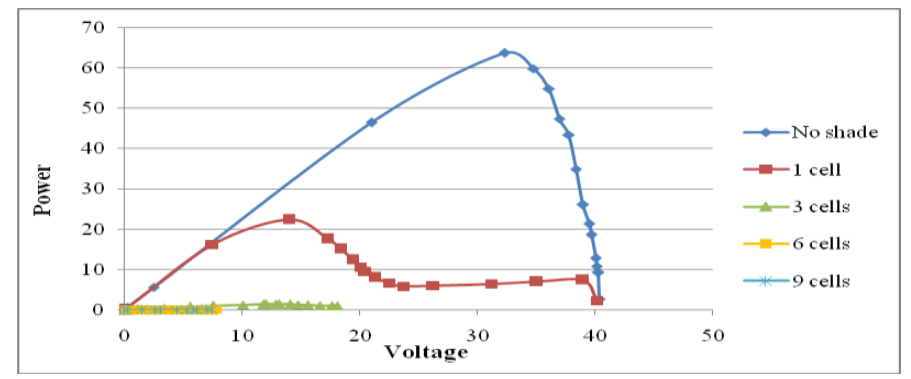

Fig.8 I-V curve for series connected PV modules with bypass diode under different shading conditions

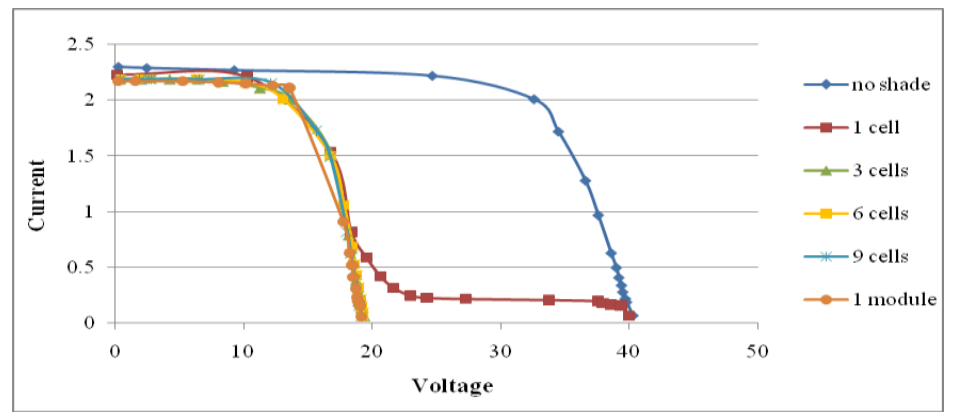


Fig.9 P-V curve for series connected PV module with bypass diode under different shading conditions

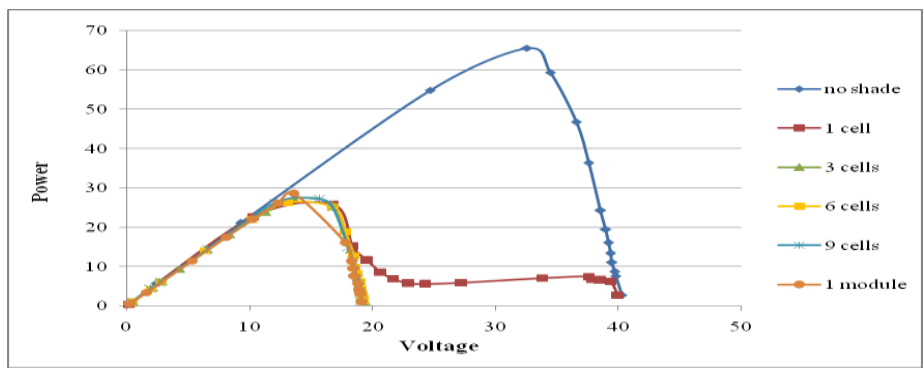

Fig.10 I-V curve when 9 cells were shaded for series connected modules with and without bypass diode

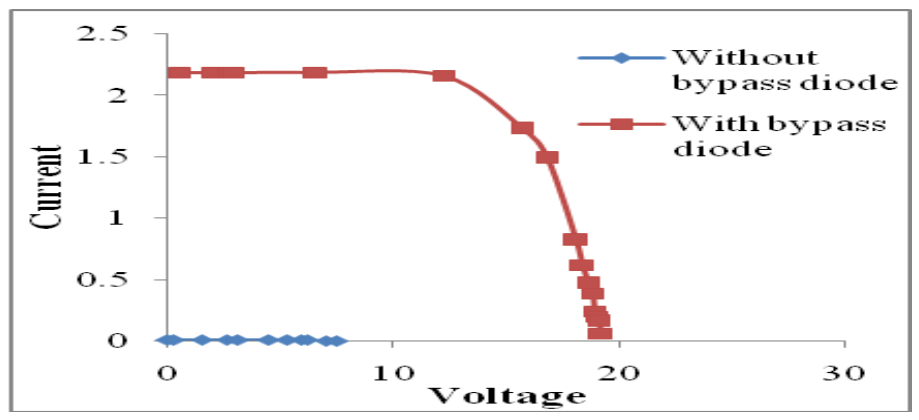

Fig.11 P-V curve when 9 cells were shaded for series connected modules with and without bypass diode

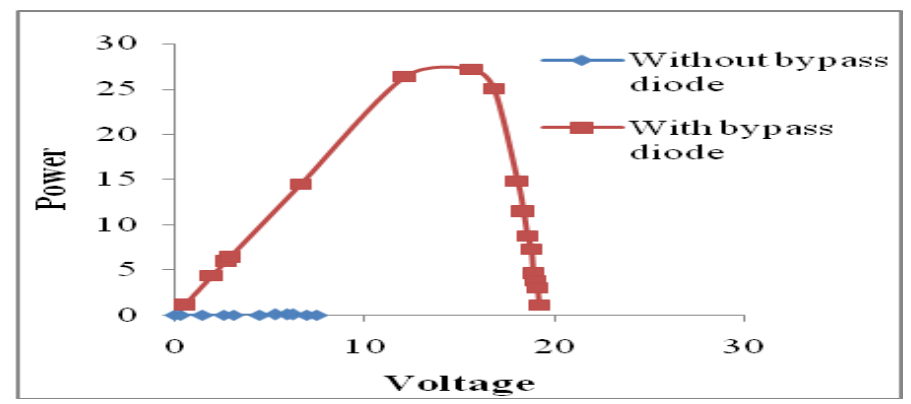

Fig.12 I-V curve for parallel connected PV modules under different shading conditions

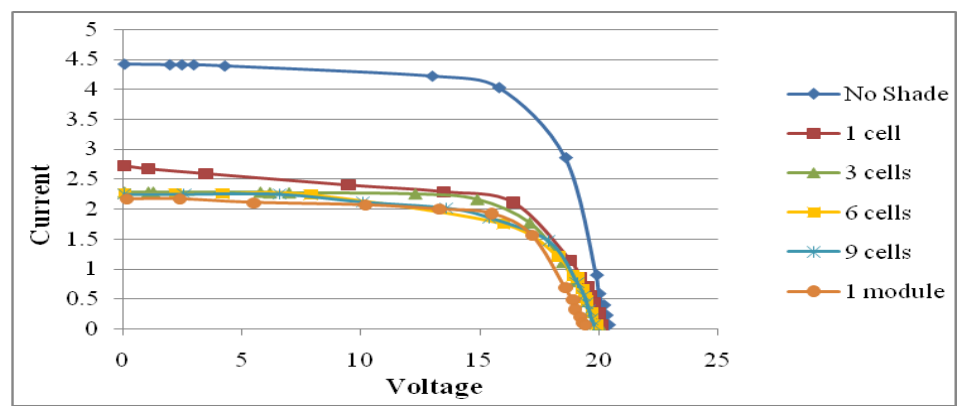


Fig.13 P-V curve for parallel connected PV modules under different shading conditions

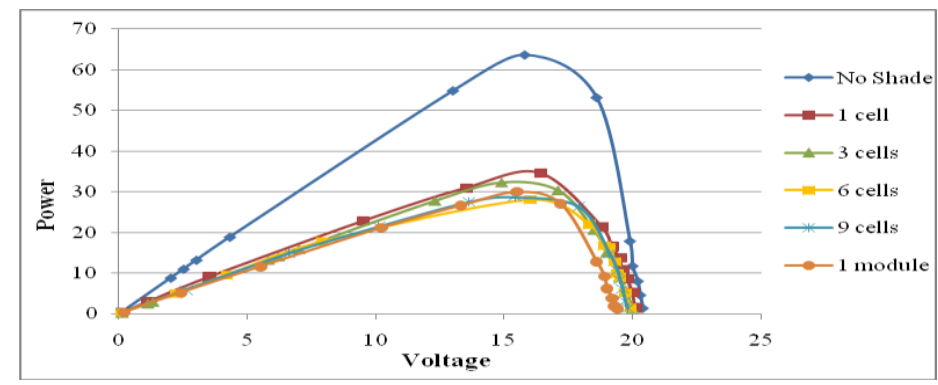

Fig.14 I-V curve for single module under soft shading

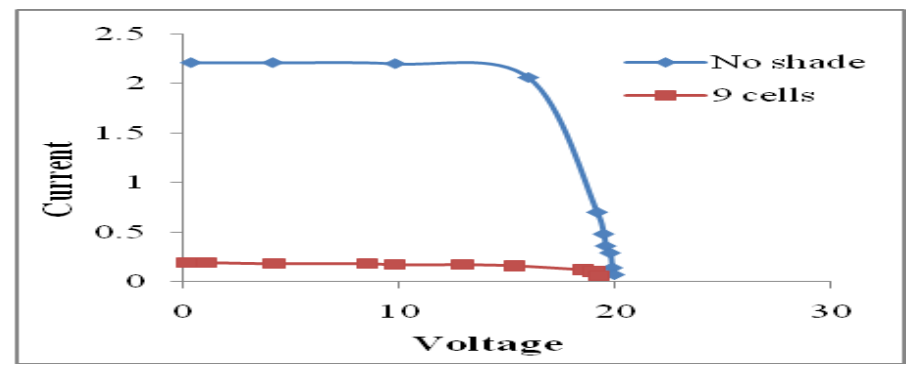

Fig.15 P-V curve for single module under soft shading

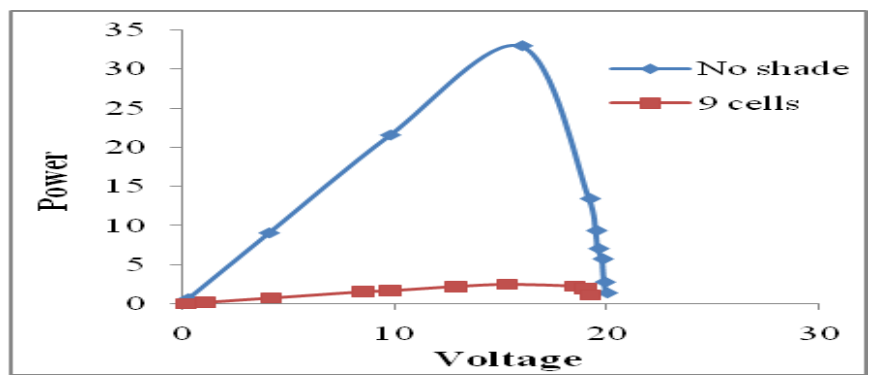

For modules in series with and without bypass diode, I -V curve was simply added along the voltage axis i.e., the output voltage $(40.4 \mathrm{~V}$ and $40.3 \mathrm{~V}$ respectively) was found to be the sum of individual modules and the current was identical (2.3A) for the both modules while in parallel combination, the voltage was found to be identical $(20.4 \mathrm{~V})$ and the current was observed to be the sum of individual modules (4.42A). Maximum Power for series $(63.631 \mathrm{~W})$ and parallel $(63.674 \mathrm{~W})$ connected modules under un-shaded conditions was almost sameas there were only two modules available for connection. It was observed that the series connected PV modules with bypass diode conducted the highest PV output power (65.5W).

\section{Effect of partial shading on PV system}

\section{Comparison curves when different module configurations were hard shaded}

The I-V and P-V curves were obtained to analyze effect of shading when different cells were shaded for each configuration of modules. Each set was affected in a different way by shading. Here the shaded conditions are compared with un-shaded condition. 
Fig. 4 and Fig. 5 shows I-V and P-V curve for hard shading on single PV module. It was observed that power for single module reduces from $32.96 \mathrm{~W}$ to $3.366 \mathrm{~W}$ for single cell shade and the module had zero power when six and nine cells were shaded.

Fig. 6 and Fig. 7 shows I-V and P-V curve for series connected PV modules without bypass diode under different shading conditions. In this case, power was reduced from $63.631 \mathrm{~W}$ to $22.4 \mathrm{~W}$ for one cell shade and power was almost zero i.e., $0.062 \mathrm{~W}$ when nine cells were shaded. To reduce the impact of shading, series connected modules were shaded with bypass diodes. The I-V and P-V curve is shown in Fig. 8 and Fig. 9. In this case, power was reduced from $65.5 \mathrm{~W}$ to $25.872 \mathrm{~W}$ when one cell was shaded but the power was not zero and maintained at around $28.696 \mathrm{~W}$ even when one complete module was shaded because the other module which was not shaded was continuously producing power.

Fig. 10 and Fig. 11 shows comparison between series connected module with and without bypass diode through I-V and P-V curves. It was observed that power reduced to zero when 9-cells of series connected modules without bypass diode were shaded but power of $26.161 \mathrm{~W}$ was obtained in series connected modules with bypass diode and further reduction in power for more shaded cells was prevented in this case due to bypass diode. It was observed that a reasonable amount of power was generated when one complete module was shaded for series with bypass diode and parallel connection of modules (Fig. 12-14).

\section{Comparison curve when single module was soft shaded}

From Fig. 15 it is clearly observed that power wasn't dropped to zero as $2.45 \mathrm{~W}$ of power was obtained when nine cells for single module were soft shaded unlike the hard shade condition. Although a considerable amount of reduction was observed as the module was not receiving any direct solar radiation for shaded region but only diffused ones.

In conclusion the energy extraction characteristics were plotted under both shaded and un-shaded conditions for each module configuration and it was observed that the reduction of power depends upon type of shade on module, shaded area and configuration of PV module. The modules in series connection with bypass diode and parallel connection delivered maximum power under shading.

\section{References}

1. Breyer, C., Bogdanov, D., Aghahosseini, A., Gulagi, A., Child, M., Oyewo, A. S., Farfan, J., Sadovskaia, K., and Vainikka, P. 2017. Solar Photovoltaics Demand for the Global Energy Transition in the Power Sector. Progress in Photovoltaics: Research and Applications, 26(8): 1-19.

2. Patel, H. and Agarwal, V. 2008. Maximum Power Point Tracking Scheme for PV Systems Operating Under Partially Shaded Conditions. IEEE Transactions on Industrial Electronics, 55(4): 1689-1698.

3. Wu, J., Zhang, L., Liu, Z., Luo, Y., Wu, Z., and Wang, P. 2020. Experimental and theoretical study on the performance of semi-transparent photovoltaic glazing façade under shaded conditions. Energy, 207: 118314

4. Patel, H. and Agarwal, V. 2008. MATLAB-based modeling to study the effects of partial shading on PV array characteristics. IEEE Transactions on Energy Conversion, 23(1): 302-310.

5. Mohammed, H., Kumar, M., and Gupta, R. 2020. Bypass diode effect on temperature distribution in crystalline silicon 
photovoltaic module under partial shading. Solar Energy, 208: 182-194.

6. Tey, K. S., Mekhilef, S., Seyedmahmoudian, M., Horan, B., Oo, A. T., and Stojcevski, A. 2018. Improved Differential Evolution-Based MPPT Algorithm Using SEPIC for PV Systems Under Partial Shading Conditions and Load Variation. IEEE Transactions on Industrial Informatics, 14 (10): 4322-4333.
Analysis of Characteristics Curves of Photovoltaic systems and MPPT Controllers under Partial Shading Conditions. International Journal of Advanced Research in Electrical Electronics and Instrumentation Engineering, 4: 953-961.

8. Anonymous 2015, Solar PV Lab Brochure (www.ecosenseworld.com/sites/default/file s/solar\%20Pv\%20Lab.pdf)

7. Panigrahy, S. and Kowsalya, M. 2015.

\section{How to cite this article:}

Parul Mertia, Surendra Kothari, Navneet Agrawal and Panwar, N. L. 2020. Experimental Analysis of Solar Photovoltaic System under Partial Shading. Int.J.Curr.Microbiol.App.Sci. 9(10): 1623-1630. doi: https://doi.org/10.20546/ijcmas.2020.910.194 